\title{
THE EFFECTS OF LEARNING MODELS AND LINGUISTIC INTELLIGENCE ON THE PERSUASIVE WRITING SKILL
}

\author{
Yusri $^{1}$, Emzir $^{2}$ \\ State Polytechnic of Sriwijaya Palembang, Indonesia ${ }^{1}$ \\ Universitas Negeri Jakarta ${ }^{2}$ \\ yusrifira@yahoo.co.id ${ }^{1}$ \\ emzir.pb@gmail.com²
}

\begin{abstract}
The objective of this study is to know the effects of learning models (problem solving and project based learning) and linguistic intelligence on the students of persuasive writing skill of the fourth semester students of English Department, State Polytechnic of Sriwijaya Palembang, in the academic year of 2016-2017. The writer used linguistic intelligence test and persuasive writing test to collect the data.

The data was analyzed statistically by using two-factor ANOVA at 0.05 significance level. The results of this study showed that (1) The students' persuasive writing skill taught through problem solving was higher than those who were taught through project based learning. (2) There was interaction effect between learning models and linguistic intelligence toward persuasive writing skill of the fourth semester students of English Department, State Polytechnic of Sriwijaya Palembang. (3) The students' persuasive writing skill who were taught by using problem solving and having high linguistic intelligence is higher than those who were taught through project based learning and having high linguistic intelligence. (4) The students' persuasive writing skill who were taught through problem solving and having low linguistic intelligence is lower than those who were taught through project based learning and having low linguistic intelligence.
\end{abstract}

Keywords: Persuasive writing, problem solving, project based learning, linguistic intelligence

Writing essay offers at least three benefits. First of all, mastering writing essay will help make you a better writer. For other courses, you'll often compose paper that will be variations on the essay form-for example, examination essay, report and research papers. Second, the discipline of writing an essay will strengthen your skills as reader and listener. As a reader, you'll become more critically aware of other writers' ideas and the evidence they provide to support those ideas. Essay writing will also help you become a better speaker. Third, writing essay will make you a stronger thinker. Writing a solid reasoned essay requires mental disciple and close attention to a set of logical rules Langan (2008:13).

The ability of someone to express ideas is also influenced significantly by intelligence levels, one of them is linguistic intelligence. In daily activities, intelligence linguistics is one of the important things since it relates with writing skills. Linguistic intelligence affects someone to communicate their points of view. 
Armstrong (2009:6-7) states that linguistic intelligence is the capacity to use words effectively, whether orally or in writing. Then according to Nelson (1998:10) linguistic intelligence involves ease in producing language and sensitivity to the nuances, order, and rhythm of words

One of the writing skills should be mastered by the fourth semester, students of English Department at State Polytechnic Sriwijaya Palembang is persuasive writing skill. In persuasive writing, the main purpose is to influence the way a reader thinks, feels or acts Camp (2007:4). More over Tala (2012:68) stated that persuasive essay is text written with the intent to persuade or convince the reader of something. Persuasive writing skill is not easy to master because to accomplish this purpose, writers need to develop a logical and reasonable argument that support that opinions. It can be concluded that ...

Problems in writing a persuasive essay based on a pilot study conducted on the third semester students of English department, state Polytechnic of Sriwijaya Palembang are as follows; the first problem relates to writing knowledge such as: difficulties in problem determination, expressing ideas or opinions, facts, arguments or data to reinforce their writing. Since in writing persuasive writing the author must be able to confront the reader to believe and behave according to what he or she thinks. Statements written should be supported by facts, data, example, arguments that support in order to convince readers of the contents of his writing.

The second problem is related to linguistic aspects such as: the mastery of English vocabulary, the selection of words or diction, the use of correct grammar, the ability to arrange paragraphs into a cohesion, coherence and unity writing . Therefore, this research needs to apply the right writing learning model so that students are able to write persuasive essay in English well. Learning models that were applied to improve students' writing skills are problem solving and project based learning. Krulik and Rudnick (1980) in Carson (2007:7) define problem solving as the means by which individual uses previously acquired knowledge, skills, and understanding to satisfy the demands of unfamiliar situation. The students must synthesize what he or she learned, and apply it to new and different situation. Then Kirkley and Foshay (2003:1-4) states that problem solving was viewed as a mechanical systematic, and often abstract set of skills, such as those used to solve riddles or mathematical equations. And according to Ormond (2006) in Doghonadze and Gorgiladze (2008:101) problem solving is using existing knowledge and skills to address an unanswered questions or troubling situation. Moreover Hozeinzadeh, Davoudi and Abed (2015:110) they state that problem solving and thinking skills are of proficiencies that should be thoughts in any eduactional systems. And Englander (2002:8) states that problem solving is interaction and collaboration among students. They talk in order to get information they want, reach decision, or solve a problem. There are some stages to in order to solve the problems. The stages are; (1) State the problem and choose one, (2) Analyze the problem, (3) Brainstorm the solutions (4) Choose two solutions, (5) Think the solutions through, (6) Identify a report-back date, (7) Follow up on the report back date.

The second learning model applied in this research to teach persuasive writing was project based learning. According to Thomas (2000:1) project based learning is a model that organizes learning around projects. It implies that projects are complex tasks, based on challenging questions or problems, that involve students in design problem-solving, decision making, or investigate activities; give students the offortunity to work relatively autonoumouslyover extended periods of time. Then Krajcik at all (1991:371) state that project based learning is comprehensive perspective focused on teaching by engaging students in investigation. And Arends (2012:396) said that project based learning consists of presenting students with authentic and meaningful problem situations that can serve as springboard for investigation and inquiry. Then Stoller and Alan 
(2005:11) state projects that are structured to maximize language, content, and real-life skill learning require a combination of reading guidance, teacher feedback, student engagement and elaborated tasks with some degree of challenge. Moreover Hunt and Beglar (2003:97) said that the project requires the learners to work in groups of two or four persons and to choose a topic they are interested in finding out more about. And according to Thitivesa (2014:2896) project based learning is described as an instructional approach that lends itself to the integration of language and content learning objectives.

Based on the above background, the writer did a research entitles " The effects of Learning Models and Linguistic Intelligence on the persuasive writing skills(Experiment Study at English Study Program, State Polytechnic of Sriwijaya Palembang)

\section{METHOD}

This study was conducted in the fourth semester of the English Department, State Polytechnic of Sriwijaya Palembang in the academic year 2017-2018. This experimental research was done four three months (February-April 2017). This research applied experimental research with treatment design by level $2 \times 2$. In this research, there were two independent variables namely; problem solving and project based learning and linguistic intelligence (high and low linguistic intelligence). Both of these independent variables gave effect on the dependent variable; persuasive writing skill. There were 40 students as the sample and the sample was taken by multistage random sampling. The writer used linguistic intelligence test and persuasive writing test to collect the data. The data was analyzed statistically by using two-factor ANOVA at 0.05 significance level.

\section{RESULTS AND DISCUSSION}

After the data was collected and analyzed. The results of this study showed that (1) The students' persuasive writing skill taught through problem solving (77.15) is higher than those who were taught through project based learning (75.15). (2) There was interaction effect between learning models and linguistic intelligence toward persuasive writing skill of the fourth semester students of English Department, State Polytechnic of Sriwijaya Palembang. It shows that Fobtained $=103.73$ is higher than Ttable $=411$, at 0.05 significance level. (3) The students' persuasive writing skill who were taught by using problem solving and having high linguistic intelligence (82.00) is higher than those who were taught by using project based learning and having high linguistic intelligence (72.00). (4) The students' persuasive writing skill who were taught by using problem solving and having low linguistic intelligence (72.30) is lower than those who were taught by using project based learning and having low linguistic intelligence (78.30).

The discussions of each hypothesis in this study are as follows:

\section{Persuasive writing skills of students who were taught with problem solving and those who were taught with project based learning}

The results of the first hypothesis reject the null hypothesis. This proves that there are differences between students who were taught with problem solving and project based learning. This hypothesis shows that students persuasive writing skills who learnt with problem solving is higher than the students who learnt with project based learning. However, the project based learning 
also contributes to student persuasive writing skills. The research also proved that problem solving is better applied to the process of learning persuasive writing skills.

\section{There is an interaction effect between the learning model (problem solving and project based learning) and linguistic intelligence (high and low) towards persuasive writing skills.}

The result of the second hypothesis rejects the null hypothesis. This proves that there is an interaction effect between learning model with linguistic intelligence to persuasive writing skill. Based on it, it can be stated that there is an interaction between students who follow the learning with the model of learning (problem solving and project based learning) with students who have linguistic intelligence (high and low) of persuasive writing skills.

The purpose of persuasive writing is to persuade, to influence readers in writing in order to do something the author or writer desires with the support of strong reasons and examples to support the author's opinion.

The problem solving learning model is a persuasive writing exercise involving students in five steps to solve a problem: identify the problem, confirm the problem, choose a strategy, apply the strategy, and evaluate the results. This learning model helps students to grow as self directed learning by giving them the opportunity to think about what they already know and what they should investigate and by encouraging them to reflect on the problem-solving process while learning takes place. Problem solving learning model does not expect students to just listen, record, then memorize the subject matter, but through problem solving approach students actively think, communicate, search and process data, and finally concluded.

learning activities are directed to solve the problem. Problem solving puts the problem as the key word of the learning process. That is, without problems there can be no defense process. Third, problem solving is done by using scientific thinking approach. Thinking using scientific methods is a process of deductive and inductive thinking. This thinking process is done systematically and empirically. Systematic means scientific thinking is done through certain stages; While empirical means the process of problem solving is based on clear data and facts. This learning model is suitable for students who have high linguistic intelligence. Because students with high linguistic intelligence have the ability to use language both orally and in writing, including rhetoric (ability to influence others), mnemonic (ability to remember something), explanation (use of language to provide information), and metalinguistics (language use to discuss the language itself).

While the learning model of project based learning is an activity that involves students in groups to write essays persuasively in writing in three steps, namely: describe the problem, identify problems and propose solutions to the problem. For students who have low linguistic intelligence, learning will be more appropriate if applied learning writing with learning model based project learning because students write with three steps without having to choose a strategy, implement the strategy and evaluate the strategy. In addition, before discussing with his friends, each student makes a paragraph describing the issues to be discussed, given the opportunity to create a paragraph of their own, they have confidence and readiness before discussing with a friend because students with low linguistic intelligence Tend to be unprepared if they immediately give their opinion before having the opportunity to write. After each student wrote them in pairs exchanged their drafts for peer editing and revision. The process of exchanging drafts and editing in pairs is very appropriate with their characteristics that they can not explain back what I read before there is preparation and discussion first. With the opportunity to write individually, the exchange of drafts and editing 
between friends on their work makes them more comfortable and influential in writing skills persuasive.

3. Persuasive writing skills to students who are learning with problem solving learning model and have higher linguistic intelligence higher than persuasive writing skill in students who gain learning with project based learning model and have high linguistic intelligence

The result of the third hypothesis rejects the null hypothesis. This proves that there are significant differences for students who have high linguistic intelligence among students who are learning with problem solving learning model and students who study with learning-based project learning model. Based on that, it is stated that students who follow the learning with problem solving learning model is higher than the students who follow the learning with the learning model of project based learning. However, the project based learning model also contributes to students' persuasive writing skills.

4. Persuasive writing skills on students who are learning with problem solving learning model and have low linguistic intelligence lower than persuasive writing skill in students who gain learning with project based learning model and have low linguistic intelligence

The result of the fourth hypothesis rejects the null hypothesis. This proves that there are significant differences for students who have low linguistic intelligence among students who follow the learning with problem solving and student learning model that follows the learning with learning-based project learning model. Based on it stated that the students who follow the learning with problem solving learning model is lower than the students who follow the learning with learning-based project learning model. However, the problem solving learning model continues to contribute to students' persuasive writing skills.

\section{CONCLUSION}

Based on the findings of this research, it can be concluded that the application of learning model in accordance with students linguistic intelligence can affect student persuasive writing skills. In students who follow the learning with problem solving learning model with high linguistic intelligence can affect the writing skill persuasive. Similarly, on the contrary, the students who follow the learning with project based learning model with low linguistic intelligence can affect the writing skills persuasive. Thus, both the learning model and the linguistic intelligence influences students' persuasive writing skills and learning models with linguistic intelligence interplay between the two.

\section{REFERENCES}

Arends, R.I. Learning to Teach, 9 $^{\text {th }}$ ed. Boston: McGraw Hill Company Inc, 2012

Armstrong Thomas. Multiple Intelligence in the Classroom. ASCD: Alexandria, Virginia, 2009. 
Camp Lindsay. Can I Change Your Mind: The Craft and Art of Persuasive Writing. A \& Black. London. 2007.

Carson Jamin. A Problem with Problem Solving Teaching Thinking without Teaching Knowledge. The Mathematics Educator, Vol 17, No 2, 7-14, 2007.

Doghonadze Natela and Gorhiladze Gulnara. Problem Solving in Teaching Foreign Languages to Students of Pedagogical Departments. IBSU Scientific Journal Vol 2 (1), 2008.

Englander Karen. Real Life Problem Solving: A Collaborative Learning Activity. English Teaching Forum. January, 2002.

Hoseinzadeh Davoud, Davoudi Mohammad Hosein Amir and Abed Soheila. The Effect of Synectics Pattern on Increasing the Level of Problem Solving and Critical Thinking Skills in Students of Alborz Province. WALIA Journal 31 :110-118, 2015.

Hunt, A. and Beglar, David. Implementing Task-Based Language Teaching: Methodology In Language Teaching: An Anthology of Current Practice. Cambridge: Cambridge University Press, 2003.

Kirkley Jamie and Foshay Rob. Principles for Teaching Problem Solving. Plato Learning Inc,:2003.

Krajcik, Marx, Ronald, Soloway Blumenfeld and Phyllis. Motivating Project Based Learning:Sustaining the Doing, Supporting the Learning. Educational Psychologist, 26 (3\&4), 369-398, 1991.

Langan John. College Writing Skills with Readings. McGraw Hill: Singapore, 2008.

Nelson Nicholson Kristen. Develoving Students' Multiple Intelligences. Scholastic Inc: New York, NY, 1998.

Stoller L and Allan B. 2005. Maximizing the Benefits of the Project Work in Foreign Language Classrooms. English Teaching Forum. 43 (4), 2005.

Tala. Write for Texas: Teaching Expository and Persuasive Texts. Texas Education Agency: Texas. 2012

Thitivesa Duangkamol. The Academic Achievement of Writing via Project Based Learning. International Journal of Social, Behavioral, Education, Economic, Business and Industrial Engineering, Vol 8 No 9, 2014

Thomas, W. John. A Review of Research on Project-Based Learning. California: The Autodesks Foundation 111 Melnnis Parkway, 2000. 